\title{
Potensi Kulit Batang Kesambi (Schleichera oleosa) Sebagai Pengawet Ikan Tongkol (Euthynnus affinis)
}

\author{
Matheos J. Takaeb ${ }^{1, *}$, Maria Nautani ${ }^{2}$ \\ 1, Peneliti Komunitas Riset Kesejahteraan Konsumen (KRKK) \\ ${ }^{2}$ Program Studi Pendidikan Biologi, Sekolah Tinggi Keguruan dan Ilmu Pendidikan Soe \\ *email korespondensi: mathewtakaeb@gmail.com
}

Received : 9 September 2019; Revised : 6 Februari 2020; Accepted : 24 Februari 2021; Published : 1 April 2021

\begin{abstract}
ABSTRAK
Masyarakat NTT mempunyai dua hasil pangan unggulan yaitu, ikan tongkol dan daging sapi. Dua hasil pangan unggulan tersebut pada umumnya digunakan oleh masyarakat marginal sebagai sumber gizi. Dalam pengolahan ikan tongkol masyarakat sering mengalami kesulitan dikarenakan Ikan tongkol mudah rusak atau busuk karena mengandung lemak dan kandungan air yang cukup tinggi. Berbeda dengan daging, masyarakat NTT menggunakan daun Kesambi (Schleichera oleosa) dalam pengasapan daging se'i karena memberikan rasa dan aroma yang khas dan daya tahan daging menjadi lebih lama. Penelitian ini mengkaji proses pengawetan ikan tongkol dengan menggunakan Kesambi (Schleichera oleosa). Metode penelitian yang digunakan dalam penelitian ini adalah penelitian eksperimen dengan metode uji organoleptik. Desain eksperimen yang digunakan adalah True Experimental Design (Sugiyono, 2009). Aktivitas antioksidan ditentukan dengan metode DPPH. Berdasarkan data pengukuran nilai absorbansi maka dapat dianalisis pengaruh konsentrasi sampel dengan nilai absorbansi, yaitu peningkatan aktivitas sebanding dengan bertambahnya konsentrasi. Penentuan aktivitas antioksidan dapat dihitung dengan persamaan y = $a x+b$ pada kurva regresi linear. Hasil variasi konsentrasi 10, 50, dan $100 \mathrm{mg} / \mathrm{L}$ yakni (10:0.04137), (50:0.19521),(100:0.19269), (C-10:0.02653), (C-50:0.04533). Sesuai dengan parameter nilai IC50, hasil menunjukkan bahwa kulit batang Kesambi merupakan antioksidan yang sangat kuat dimana (nilai $x<50)$. Hasil uji organoleptik warna ikan tongkol tetap cerah dan bertahan pada hari 1 dan 2, aroma ikan bertahan pada 1 hari, dan uji rasa berahan 1-2 hari.
\end{abstract}

Kata kunci: antioksidan; ikan Tongkol; kulit batang Kesambi; organoleptik; pengawet makanan

\section{PENDAHULUAN}

Tanaman Kesambi (Schleichera oleosa) dan ikan tongkol (Euthynnus affinis) termasuk salah satu pangan potensial yang banyak ditemukan di Nusa Tenggara Timur (NTT). Kesambi sering digunakan oleh masyarakat NTT sebagai salah satu pengawet untuk daging sapi dan ikan tongkol yang menjadi makanan pokok masyarakat marginal. Diketahui dari data BPS statistik NTT bahwa produksi tangkapan ikan tongkol di NTT termasuk cukup tinggi tahun 2016 sebanyak 10.373 .57 ton. Akan tetapi, selain memiliki kandungan gizi yang tinggi, Ikan tongkol termasuk bahan pangan yang mudah rusak atau busuk karena mengandung lemak dan kandungan air yang cukup tinggi.

Melalui penelitian Lopi, Sipahelut, \& Sabtu (2015) pada bahan pangan daging sapi menunjukkan bahwa penggunaan asap cair Kesambi, dimana meningkatkan kandungan protein, rasa dan menurunkan kandungan air, lemak, dan kolesterol se'i sapi. Level pemberian asap cair pada pengolahan se'i sapi yang terbaik adalah $12 \%(\mathrm{w} / \mathrm{v})$.

Selain daun, biji Kesambi juga diolah menjadi minyak. Sudradjat et al. (2010) menyatakan bahwa minyak biji Kesambi dapat pula diolah menjadi salep, pembuatan biodisel, minyak pelumas, pembuatan lilin, tinta untuk batik, dan sabun mandi. Sedangkan pengolahan dalam bentuk obat-obatan berguna untuk pengobatan penyakit kulit, kerontokan rambut, jerawat, kudis dan luka-luka. Diketahui senyawa saponin dan tanin yang terdapat dalam Kesambi yang berfungsi sebagai antioksidan (Holil \& Griana, 2020). Pianusa et al. (2016) dalam penelitiannya mengatakan bahwa antioksidan yang terdapat dalam batang Kesambi sebanyak 5-7,5 gram dapat mempertahankan kesegaran nira pada saat penyadapan. Selain dipakai untuk nira, kulit batang Kesambi juga digunakan dalam pengawetan tahu untuk mempertahankan tekstur dan kesegaran (Sukri, 2013). 
Beberapa penelitian terdahulu mengungkapkan bahwa pemanfaatan Kesambi sebagai pengawet dapat dilakukan untuk bahan pangan. Berdasarkan permasalahan dan potensi yang ada maka penulis melakukan penelitian dengan judul "potensi kulit batang Kesambi (Schleichera oleosa) sebagai pengawet pada ikan tongkol".

\section{EKSPERIMEN}

\section{Waktu dan Tempat}

Penelitian dilaksanakan di Laboratorium Eksakta Universitas Kristen Artha Wacana Kupang pada bulan Juni 2018.

\section{Alat dan Bahan}

Alat-alat yang digunakan dalam penelitian ini adalah blender, timbangan, cawan petri, gelas ukur, dan 15 buah toples. Bahan-bahan yang digunakan dalam penelitian ini adalah 20 liter air, 15 ekor ikan tongkol dengan berat $250 \mathrm{~g} / \mathrm{ekor}$, dan kulit batang Kesambi.

\section{Desain Penelitian}

Metode penelitian yang digunakan dalam penelitian ini adalah penelitian eksperimen. Menurut (Sugiyono, 2017), Desain eksperimen yang digunakan adalah True Experimental Design.

\section{Tahapan Penelitian}

\section{Preparasi sampel}

Sampel yang digunakan dalam penelitian ini adalah kulit batang Kesambi yang diambil dari Kelurahan Nonohonis, Kabupaten Timor Tengah Selatan seberat $5 \mathrm{~kg}$. Sampel kulit batang Kesambi dibersihkan, dipotong tipis-tipis dan dikeringkan. Sampel kering dihaluskan sampai menjadi serbuk halus.

Serbuk kering kulit batang Kesambi dimaserasi dengan pelarut etanol pada suhu ruang selama 76 Jam. Ekstrak kemudian disaring untuk mendapatkan filtrat dan residu, kemudian residu dimaserasi kembali dengan etanol sampai didapat larutan jernih. Ekstrak etanol kulit batang Kesambi dipekatkan dengan rotari evaporator sehingga diperoleh ekstrak kental (Sudradjat et al., 2010)

\section{Aktivitas Antioksidan Kulit Batang Kesambi}

Uji aktivitas antioksidan dilakukan ekstrak etanol kulit batang Kesambi ditentukan menggunakan metode DPPH. Penelitian ini menggunakan asam askorbat sebagai pembanding (kontrol positif). Uji aktivitas antioksidan diawali dengan pembuatan larutan sampel kulit batang Kesambi. Sampel diencerkan dengan pelarut etanol untuk mendapatkan variasi konsentrasi 10, 50, dan $100 \mathrm{mg} / \mathrm{L}$. Selanjutnya dilakukan uji yang sama untuk larutan pembanding yaitu larutan asam askorbat dengan variasi 10 dan $50 \mathrm{mg} / \mathrm{L}$ dengan tujuan untuk mengetahui besarnya nilai absorbansi dari konsentrasi pembanding yang terkecil. Pereaksi DPPH dibuat dalam konsentrasi sebanyak $40 \mathrm{mg} / \mathrm{L}$ dan harus dijaga pada suhu ruang dan terlindung cahaya karena DPPH mudah teroksidasi. Selanjutnya adalah pencampuran larutan sampel dan larutan pembanding dengan pereaksi DPPH dan diinkubasi pada suhu ruang selama 30 menit sebelum dilakukan pengukuran dengan Spektrofotometer UV-Vis pada panjang gelombang $518 \mathrm{~nm}$.

Berdasarkan data pengukuran nilai absorbansi maka dapat dianalisis pengaruh konsentrasi sampel dengan nilai absorbansi, yaitu peningkatan aktivitas sebanding dengan bertambahnya konsentrasi. Penentuan aktivitas antioksidan dapat dihitung dengan persamaan $y=a x+b$ pada kurva regresi linear.

\section{Uji Organoleptik}

Uji organoleptik ini menggunakan panelis agak terlatih sejumlah 15 orang yang dipilih dari mahasiswa politani jurusan THP yang memiliki tingkat kepekaan yang tinggi terhadap Warna, Aroma dan Rasa. Dalam uji ini panelis memberi tanggapan terhadap warna, aroma, rasa pada masa simpan ikan tongkol. Uji organoleptik ini dipakai beberapa ruang yang terdiri dari bagian persiapan (dapur), ruang pencicip dan ruang tunggu atau ruang diskusi. Dalam evaluasi sensori ini juga peneliti memperhatikan estetika seperti suhu ruang $\left(20-25^{\circ} \mathrm{C}\right)$, ukuran, kode, dan jumlah contoh. Selain memperhatikan estetika 
untuk tiap panelis peneliti juga memperhatikan waktu penyajian dan urutan penyajian agar tidak mempengaruhi penilaian panelis terhadap sampel yakni expectation error, convergen error, stimulus error, logical error, halo efek, efek kontras, motivasi, sugesti dan posisi bias. Setelah memperhatikan estetika dan waktu peneliti melakukan 5 perlakuan dengan 3 ulangan untuk memperoleh hasil yang baik yakni sampel 0 sebagai kontrol atau tidak diberi perlakuan, sampel 1 diberi kulit batang Kesambi seberat 12,7 gram; sampel 2 diberi kulit batang Kesambi seberat 19,1 gram; sampel 3 diberi kulit batang Kesambi seberat 25,4 gram; dan sampel 4 diberi kulit batang Kesambi seberat 31,8 gram.

\section{HASIL DAN PEMBAHASAN}

\section{A. Aktivitas Antioksidan Kulit Batang Kesambi}

Hasil pengukuran antioksidan kulit batang Kesambi dapat dilihat pada Tabel 1. Konsentrasi antiosidan pada kulit batang Kesambi dengan DPPH serta kurva regresi linier untuk melihat perbedaan dilakukan uji ANOVA satu arah dengan nilai signifikansi $p<0,01$. Pengulangan pengukuran sampel dilakukan sebanyak 2 kali serta di analisis secara deskriptif.

Tabel 1. Konsentrasi Antioksidan Pada Kulit Batang Kesambi dengan 2 Pengulangan

\begin{tabular}{cc}
\hline Sampel $(\mathbf{m g} / \mathrm{L})$ & Konsentrasi Antioksidan \\
\hline 10 & 0,04137 \\
50 & 0,19521 \\
100 & 0,19269 \\
$\mathrm{C}-10$ & 0,02653 \\
$\mathrm{C}-50$ & 0,04533 \\
\hline
\end{tabular}

Tabel 1 diatas menunjukkan bahwa konsentrasi antioksidan pada sampel $10 \mathrm{mg} / \mathrm{L}$ hampir setara dengan sampel pembanding asam askorbat $50 \mathrm{mg} / \mathrm{L}$. Hal ini menunjukkan bahwa kadar antioksidan pada kulit batang Kesambi pada sampel terkecil sebanding dengan kadar antioksidan pada sampel pembanding terbesar.

B. Hasil Uji Organoleptik Keadaan Ikan Tongkol

Hasil anova dua arah disajikan berdasarkan 3 kelompok variabel, yaitu variabel warna, aroma, dan rasa.

1. Keadaan Warna ikan Tongkol

Gambar 1.

Perubahan warna ikan tongkol pada masa penyimpanan selama tiga hari dapat dilihat pada

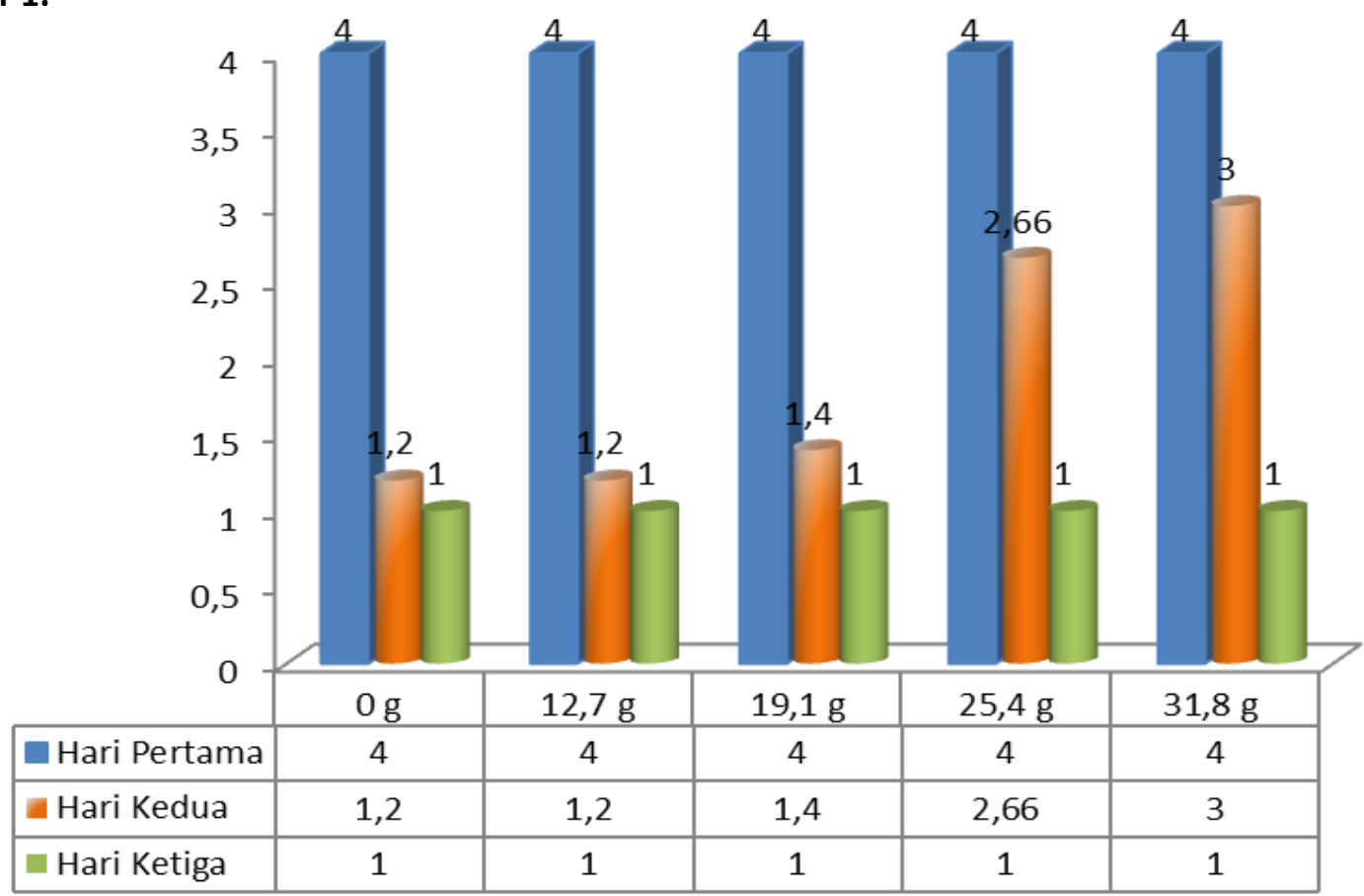

Gambar 1. Rata-rata Skor Panelis Terhadap Perubahan Warna Ikan Selama Tiga Hari Penyimpanan (4 = Sangat Cerah, 3= Cerah, 2= Cukup Cerah, 1= Pucat) 
Gambar 1 menunjukkan bahwa warna ikan tongkol pada hari pertama untuk semua jenis perlakuan masih sangat cerah. Pada hari kedua, keadaan ikan tongkol untuk perlakuan kontrol, perlakuan 12,7 gram dan perlakuan 19,1 gram kulit ikan sudah berwarna pucat dan mata berwarna merah. Sedangkan pada perlakuan 25,4 gram dan perlakuan 31,8 gram keadaan ikan pada hari kedua masih cerah atau masih baik untuk dikonsumsi. Keadaan warna kulit ikan tampak pucat dan mata berwarna merah pada penyimpanan hari ketiga untuk semua jenis perlakuan. Hal ini menunjukkan bahwa pada hari ketiga, ikan tongkol sudah tidak dapat dikonsumsi. Perubahan warna ikan pada hari kedua dan ketiga disebabkan oleh adanya aktivitas bakteri pembusuk, perubahan enzim dan proses oksidasi lemak tak jenuh pada tubuh ikan.

Menurut Syafitri, Metusalach, \& Fahrul (2016), ikan yang masih segar mempunyai penampakan cerah, warna mata bening, insang berwarna merah dan tidak ditemukan tanda-tanda perubahan warna. Sedangkan ikan mulai kelihatan rusak atau busuk apabila warna ikan mulai menunjukkan tanda-tanda perubahan warna seperti kulit pucat, mata tidak bening, dan insang tidak lagi berwarna merah.

2. Keadaan Aroma Ikan Tongkol

Perubahan aroma ikan tongkol selama tiga hari penyimpanan dapat dilihat pada Gambar 2.

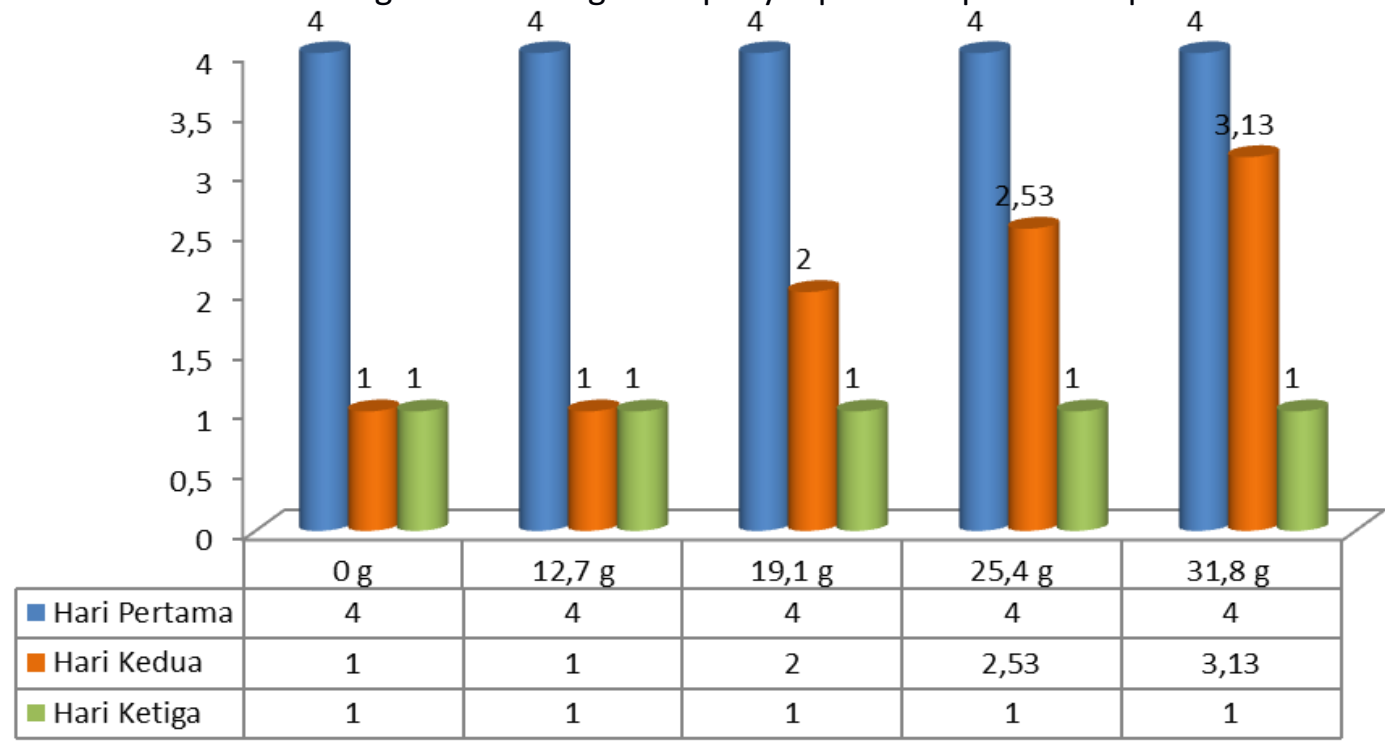

Gambar 2. Rata-rata Skor Panelis Terhadap Perubahan Aroma Ikan Selama Tiga Hari Penyimpanan (4= Sangat Amis, 3= Cukup Amis, 2= Cukup Kecut, 1= Kecut)

Gambar 2 menunjukkan bahwa pada hari pertama keadaan aroma ikan masih sangat amis pada semua jenis perlakuan. Sedangkan pada hari kedua aroma ikan mulai berubah. Pada perlakuan kontrol dan perlakuan 12,7 gram menunjukkan bahwa aroma ikan sangat kecut, sedangkan perlakuan 19,1 gram cukup kecut yang menandakan bahwa ikan mulai mengalami pembusukan. Pada perlakuan 25,4 gram dan 31,8 gram keadaan aroma ikan cukup amis atau baik untuk dikonsumsi. Keadaan ikan pada hari ketiga menunjukkan bahwa aroma ikan sudah sangat kecut pada semua jenis perlakuan termasuk perlakuan 25,4 gram dan 31,8 gram.

Hasil analisis gambar 2 menunjukkan bahwa serbuk kulit batang Kesambi dan lama penyimpanan memberikan pengaruh yang nyata terhadap perubahan aroma ikan tongkol. Hal ini menunjukkan bahwa zat-zat yang terkandung dalam kulit batang Kesambi dapat menghambat pertumbuhan bakteri pembusuk dan dapat menghambat proses oksidasi lemak tak jenuh pada masa simpan ikan sehingga aroma ikan dapat bertahan hingga tiga hari penyimpanan.

3. Keadaan Rasa Ikan Tongkol

Hasil analisis sidik ragam berdasarkan perubahan kualitas rasa ikan tongkol selama masa simpan tiga hari dapat dilihat pada Gambar 3. Gambar 3 menunjukkan bahwa pada hari pertama rasa ikan tongkol untuk semua jenis perlakuan masih sangat kenyal. Hal ini menunjukkan bahwa keadaan ikan tongkol pada hari pertama masih sangat segar. Pada hari kedua, rasa ikan tongkol untuk semua jenis perlakuan mengalami penurunan kualitas rasa dan perubahan rasa yang sangat mencolok terlihat pada kelompok kontrol, kelompok 12,7 gram dam kelompok 19,1 gram. Sedangkan pada kelompok 25,4 gram dan 31,8 gram mengalami sedikit penurunan kualitas rasa. Pada hari ketiga, rasa ikan tongkol sangat gatal dimulut ketika dikonsumsi. Hal ini menunjukkan bahwa ikan tidak dapat dikonsumsi karena penurunan kualitas rasa ikan yang sangat mencolok. 


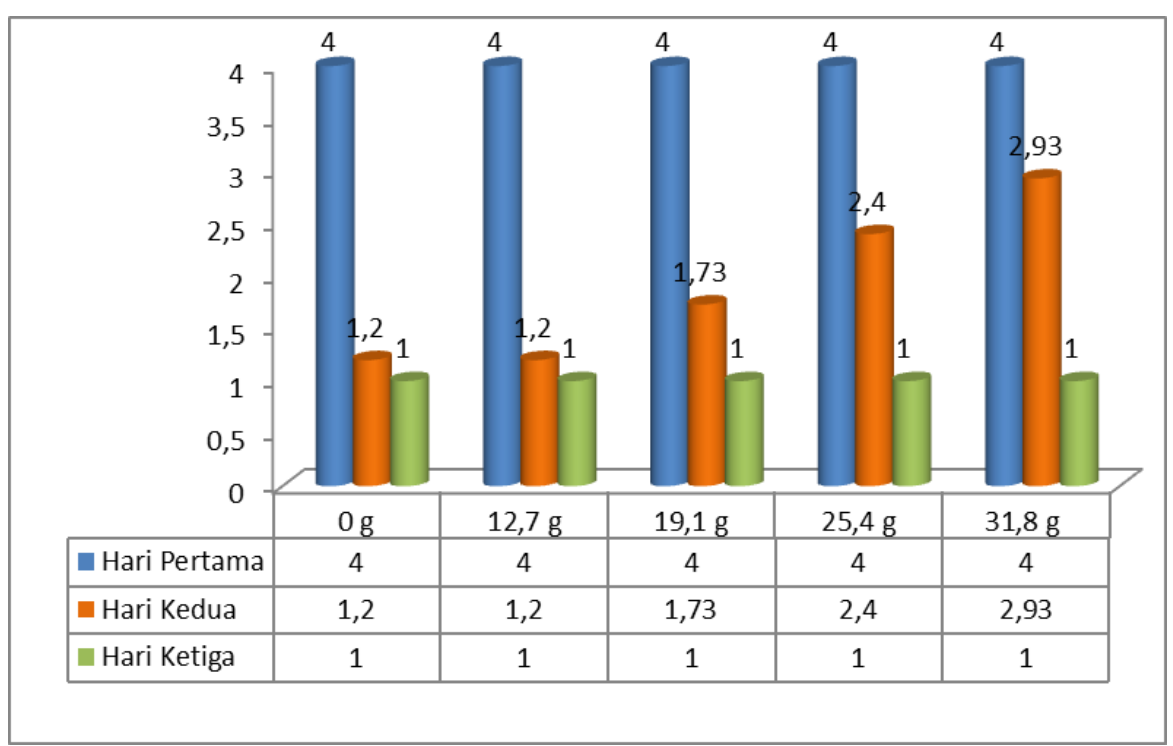

Gambar 3. Rata-rata Skor Panelis Terhadap Perubahan Rasa Ikan Selama Tiga Hari Penyimpanan (4= Sangat Kenyal, 3= Cukup Kenyal, 2= Agak Gatal Dimulut, 1= Sangat Gatal Dimulut)

Berdasarkan hasil Gambar 3 maka dapat dilihat bahwa semakin tinggi penggunaan konsentrasi antioksidan, maka masa simpan ikan akan semakin lama. Hasil analisis sidik ragam menunjukkan ada pengaruh signifikan terhadap perubahan warna, aroma dan rasa yaitu $\operatorname{Sig}(0,01)<\boldsymbol{\alpha}(0,05)$.

Berdasarkan perbandingan nilai mean (rata-rata) dari hasil analisis antara perlakuan kontroll dengan perlakuan serbuk, penurunan kualitas warna, aroma dan rasa ikan pada hari kedua sangat mencolok sedangkan pada perlakuan serbuk kulit batang Kesambi tidak begitu mengalami penurunan yang berarti. Menurut (Anonim, 2013) penurunan kualitas ikan tongkol terjadi akibat pertumbuhan bakteri pembusuk $\left(\mathrm{H}_{2} \mathrm{~S}\right)$, aktifitas enzim dan oksidasi lemak.

Penurunan kualitas ikan tongkol pada perlakuan serbuk disebabkan oleh senyawa-senyawa kimia pada kulit batang Kesambi seperti saponin dan tanin. Senyawa-senyawa kimia ini dapat berfungsi sebagai pengawet dengan cara menghambat pertumbuhan dan perkembangbiakan bakteri pembusuk pada ikan tongkol (Mumpuni \& Hasibuan, 2018)

Senyawa saponin dan tanin bekerja sebagai antibakteri dengan cara merusak sel bakteri. Saponin dapat menganggu stabilitas permeabilitas membran sel bakteri yang dapat menyebabkan sel bakteri lisis, sehingga membran sel akan mengalami kerusakan yang menyebabkan keluarnya berbagai komponen-komponen penting dari dalam sel bakteri, seperti protein, asam nukleat, nukloetida dan lainlain, yang kemudian dapat membuat bakteri tersebut mati (Fadlian, Hamzah, \& Abram, 2017). Senyawa tanin dapat mendenaturasi dan koagulasi protein pada sel bakteri, sehingga dapat meningkatkan permeabilitas membran sel pada bakteri yang mengakibatkan gangguan terhadap fungsi membran sel. Dampak dari terganggunya fungsi membran sel adalah kerusakan pada sel bakteri sehingga dapat membuat kematian pada sel bakteri (Fitri, 2007).

\section{KESIMPULAN}

Berdasarkan hasil penelitian diperoleh kesimpulan bahwa kulit batang Kesambi (Schleichera oleosa) berpotensi sebagai pengawet pada ikan tongkol (Euthynnus affinis. Penggunaan variasi jumlah kulit batang Kesambi pada ikan tongkol sangat berpengaruh pada lama penyimpanan ikan tongkol. Hasil variasi konsentrasi 10, 50, dan $100 \mathrm{mg} / \mathrm{L}$ yakni (10:0.04137), (50:0.19521),(100:0.19269), (C-10:0.02653), (C50:0.04533). Sesuai dengan parameter nilai $I_{50}$, hasil menunjukkan bahwa kulit batang Kesambi merupakan antioksidan yang sangat kuat dimana (nilai $x<50$ ). Hasil uji organoleptik warna ikan tongkol tetap cerah dan bertahan pada hari 1 dan 2, aroma ikan bertahan pada 1 hari, dan uji rasa berahan 1-2 hari.

\section{UCAPAN TERIMA KASIH}

Penulis mengucapkan terima kasih kepada Forum Peneliti Komunitas Riset Kesejahteraan Konsumen (KRKK) dan STKIP Soe yang telah memberikan kesempatan pada Tahun Anggaran 2018 untuk dapat melaksanakan penelitian. 


\section{DAFTAR PUSTAKA}

Anonim. (2013). Kandungan Gizi Dan Manfaat Buah Mangga. tanamanobat-herbal.blogspot.com > buahbuahan

Fadlian, F., Hamzah, B., \& Abram, P. H. (2017). Uji Efektivitas Ekstrak Tanaman Putri Malu (mimosa pudica linn) Sebagai Bahan Pengawet Alami Tomat. Jurnal Akademika Kimia, 5(4), 153. https://doi.org/10.22487/j24775185.2016.v5.i4.8063

Fitri, A. (2007). Pengaruh Penambahan Daun Salam (Eugenia polyantha Wight) Terhadap Kualitas Mlikrobiologis, Kkualitas Organoleptis Dan Daya Simpan Telur Asin Pada Suhu Kamar. Surakarta: Jurusan Biologi Fakultas MAatematika Dan Ilmu Pengetahuan Alam Universitas Sebelas Maret.

Holil, \& Griana. (2020). Analisis Fitokimia dan Aktivitas Antioksidan Ekstrak Daun Kesambi (Schleichera oleosa) Metode DPPH. 5(1), 28-32.

Lopi, F., Sipahelut, H. M., \& Sabtu, B. (2014). Efek Penggunaan Asap Cair Kusambi (Schleichera oleosa) Pada Level Yang Berbeda Terhadap Kandungan Nutrisi , Kolesterol Dan Rasa Daging Se 'I Sapi. 1(2), 117122.

Mumpuni \& Hasibuan. (2018). Prevalensi Mikroba Pada Produk Pindang Tongkol Skala Ukm Di Pelabuhan Ratu, Sukabumi. 21(2014).

Pianusa, A. F., Sanger, G., \& Wonggo, D. (2016). Kajian Perubahan Mutu Kesegaran Ikan Tongkol (Euthynnus Affinis) Yang Direndam Dalam Ekstrak Rumput Laut (Eucheuma spinosum) Dan Ekstrak Buah Bakau (Sonneratia alba). Media Teknologi Hasil Perikanan, 4(2), 66. https://doi.org/10.35800/mthp.4.2.2016.12927

Sudradjat, R., Pawoko, E., Hendra, D., \& Setiawan, D. (2010). ( Schleichera oleosa L .) ( Biodiesel Manufacturing from Kesambi Seed ). 358-379.

Sugiyono. (2017). Statistika Untuk Penelitian (Sugiyono (ed.); Cetakan ke). Penerbit Alfabeta.

Sukri. (2013). Pemanfaatan Kulit Kayu Kesambi Sebagai Antioksidan pada Tahu.

Syafitri, S., Metusalach, M., \& Fahrul, F. (2016). Studi Kualitas Ikan Segar Secara Organoleptik Yang Dipasarkan Di Kabupaten Jeneponto. Jurnal IPTEKS PSP, Prodi Pemanfaatan Sumberdaya Perikanan, Fakultas IImu Kelautan Dan Perikanan, Universitas Hasanuddin, 3(6), 544-552. 